Kansas State University Libraries

New Prairie Press

\title{
EFFECT OF GENETIC POTENTIAL AND FEED ON GROWTH OF YOUNG BULLS FOR FUTURE BREEDING
}

Benjamin G. Mullinix

Walter E. Neville

Jerry F. Baker

Follow this and additional works at: https://newprairiepress.org/agstatconference

Part of the Agriculture Commons, and the Applied Statistics Commons

\section{cc) (1) $\Theta$}

This work is licensed under a Creative Commons Attribution-Noncommercial-No Derivative Works 4.0 License.

\section{Recommended Citation}

Mullinix, Benjamin G.; Neville, Walter E.; and Baker, Jerry F. (2003). "EFFECT OF GENETIC POTENTIAL AND FEED ON GROWTH OF YOUNG BULLS FOR FUTURE BREEDING," Conference on Applied Statistics in Agriculture. https://doi.org/10.4148/2475-7772.1178

This is brought to you for free and open access by the Conferences at New Prairie Press. It has been accepted for inclusion in Conference on Applied Statistics in Agriculture by an authorized administrator of New Prairie Press. For more information, please contact cads@k-state.edu. 


\title{
EFFECT OF GENETIC POTENTIAL AND FEED ON GROWTH OF YOUNG BULLS FOR FUTURE BREEDING ${ }^{1}$
}

\author{
Benjamin G. Mullinix ${ }^{2}$ \\ Walter E Neville ${ }^{3}$ \\ Jerry F. Baker ${ }^{4}$
}

1) Part of this research has already been published in J. Animal Science 80:17161724 (2002) by J. F. Baker et al. and in UGA, CAES, DADS, 1999 Annual Report, pp. 10-16 (2000) by J. F. Baker et al.

2) Ag. Research Statistician, Experimental Statistics, UGA-CAES.

3) Professor, Animal and Dairy Science Department, UGA-CAES (Retired).

4) Professor and REI Coordinator, Animal and Dairy Science Department, UGACAES.

Tifton Campus

Tifton, Georgia 31793-0748 


\begin{abstract}
Over a five-year period (1985-1989), a total of 239 bull calves (Angus=119, Hereford $=120$ ) were weaned and placed on summer pasture or fed grain concentrate in a feedlot for purpose of studying growth rate of body weight, hip height, and scrotal circumference over 189 days. Average daily gain [ADG, (final wt - weaning wt) / days in period] has been the standard measure of growth. However, this does not address how well a particular bull might have performed. ADG values were ranked at each measurement period $(0,21,49,77,105,133,161$ and 189 days after weaning), changes in rank were determined for each bull, and the data analyzed. Bulls with higher genetic potential and those on the grain-fed diet showed positive rank changes over the 189 days. It was concluded that rank changes would be the best measure of superior growth for future breeding purposes. It was discovered that a bull, poorly prepared (genetic or environmental) prior to weaning, could overcome this if placed on the grain-fed diet.
\end{abstract}

\title{
INTRODUCTION
}

There are several considerations concerning the management of beef operations. First, beef cattle are bred to achieve greater and/or more efficient weight gains for calves to be sold in the market place. Second, beef bulls are expected to get the cows pregnant. Estimation of sire and dam effects are important in both instances (Robison, 1981). Third, beef dams are expected to produce calves that are healthy and eat forage when her milk production is not very high. Beef calves stay with the cows for a long time (ca. 240 days).

Selecting beef bulls for future breeding is a gamble at best since it is difficult to determine how well they will perform as newly weaned calves. Some beef ranchers are able to conduct some type of evaluative trial on their own premises under guidelines established by the Cooperative Extension Service or the beef breed's association. However, most cannot afford such on-site trials or they do not have the time to conduct such trials. State agricultural universities in conjunction with their Cooperative Extension Service have facilities that are equipped to do this evaluation of the young bulls. However, the contract signed by the grower either specifies the rancher give up ownership of the tested bulls or the rancher agrees to pay for all the feed his bull(s) will consume during the bull test period. Since the number one criteria for judging a young bull for future breeding is weight gain, all bulls assigned to the Bull Test Station in a particular state are compared on basis of weight gain which most commonly is presented as average daily gain (usually in pounds day ${ }^{-1}$ ). Those bulls whose ownership is transferred to the Station are auctioned off at the end of the testing period. Nothing prevents the original owner of the bull to bid on and buy back his bull. Those bulls whose weight gains are impressive will obtain a higher price.

The problem, when the calves are born, which male calf will be made a steer by way of castration (an irreversible process) or kept as a potential breeding bull. Holland and Odde (1992) reviewed the literature concerning calf birth weight. Too low calf birth weight increases the possibility that the calf will not make it to weaning due to disease, 
failure to adapt to surviving on milk and grass, etc. Whereas, too heavy calf birth weight, a real problem due to emphasis on heavy marketable steers and baby bulls, increases the risk of injury to the cow, birthing death, etc. Calf death rates vary from 1 to $30 \%$.

At weaning, another decision is made concerning those bulls based on average daily gain when with the cow. Low achievers will be finished out and sold as baby bulls (before $6-8$ months old). The remaining bulls will be prepared for breeding as yearling bulls. It is a risky business since one never knows if a bad decision was made concerning a castrated male calf, while one has to second guess a decision to keep the calf and discover later that weight gains did not measure up. This decision making process is particularly difficult for beef operation with smaller numbers of cows. Spillman (2003) reported that collaboration between USDA beef breeders and industry, a software program has been developed that predicts the future value of a calf from the proposed breeding between a bull and a cow. Excellent records must be kept on bulls and cows for this software to work, but the results can be used to prevent a possible bad breeding match from taking place. Pordomingo et al. (1998) examined the effects that feeding strategy has on early-weaned calves. The older a weaned calf was, the higher the weight gain day ${ }^{-1}$. The same weaning age relationship did not occur with the control group. The youngest early-weaned calves gained the most but the gain was not significantly different from that of the two older age groups.

The type of feed available during the growth of the calf during the cow-calf phase and then during the post-weaning phase will largely determine the final outcome: Is the bull ready for breeding? Drouillard and Kuhl (1999) discussed the problems faced by feedlot operators when steers for finishing come from diverse grazing backgrounds and various levels of nutrition. Nutrition for young bulls is similar to that of steers and is dependent on how gain is desired and how fast this gain should occur. Summer forage is much better than winter forage, while spring forage is probably the best, and fall forage is better than winter forage. Obviously, depending on the beef operation, calving may occur anytime during the year. Since spring forage is the best in the southeastern Coastal Plain, calving begins in December so that when weaning occurs, weaned calves can access good to excellent forage. Creep-feeding calves prior to weaning does improve calf weight gains, but research shows that post weaning weight gains are largely unaffected. Studies of grain supplemented grazing during the post-weaning period prior to the finishing phase in the feedlot have not produced definitive results. Implants placed before or after weaning, although useful in achieving early post-weaning weight gains, seldom have any carryover effects on the finishing phase performance of steers. Klopfenstein et al. (2000) examined the effects of backgrounding and growing programs on beef carcass quality. Muscle tissue toughens when male hormones in a young bull are released at the onset of puberty (ca 8-10 months of age). With all the diverse backgrounds that beef feedlot operators must face when accepting steers for finishing before they are marketed, they examined carcasses from a large sample of finished steers to determine the effect of background preparation (type of forage and management scheme employed) on carcass quality (Jordon et al., 1998; Pritchard, 1998; Weakley and Reutzel, 1998). The biggest relationship was backfat thickness versus steak quality, the thicker the backfat the better the quality. However, steak quality was mediated by amount of marbling due to increased 
backfat thickness. Whether the steer was received from a summer forage program or a winter forage program, had no effect on the backfat thickness versus steak quality relationship. Separating the steers into fast and slow gaining groups also showed no differential effect on the relationship of backfat thickness versus steak quality (Janloo et al., 1998).

An experiment was designed to test whether pre-weaning preparation and/or postweaning finishing could reduce the importance of the genetic evaluation of its sire in predicting the performance of the bull calf. The most accepted measure of performance continues to be average daily gain (ADG), yet the best measure of future performance as a breeding bull is the size of its scrotum (holds the semen) which can be measured as the scrotal circumference at a point where it is usually the greatest. A bull in excellent breeding condition should be able to mount 1-5 cows day ${ }^{-1}$. Since the estrus cycle of cows is 28-30 days (similar to humans), in a 90-day breeding period, majority of cows should have at least two peak times to be inseminated thus giving the bull ample opportunity to breed with them. Generally, once a cow has been bred (inseminated) and conceived, she does not have another estrus cycle until after the calf is born.

\section{METHODS AND MATERIALS}

During the preceding year (1984), four to six sires of each breed, Angus and Hereford, were selected based on their average daily gain (ADG) during a pre-weaning and post-weaning phase (189 days). The two or three bulls with the highest ADG were assigned to a class called high genetic potential (Line $=\mathrm{H}$ ), and the two or three bulls with the lowest $\mathrm{ADG}$ were assigned to a class called low genetic potential (Line $=\mathrm{L}$ ). Those buils between these extremes were not considered. Each bull (Figure 1 \& Table 1) was assigned to 30-40 cows of the same breed during the 1984-1985 breeding season. Once the dams began calving, the first 24 dam-bull calf pairs of each breed, Angus and Hereford, were randomly assigned to one of two pasture treatments, winter pasture only (WP) or winter pasture plus creep feeding for calves only (CP), until the calves were weaned [pre-weaning phase (BW)]. This process was repeated in 1985-1986, 1986-1987, 1987-1988, and 1988-1989. The age of the dam, and birth and weaning weights of the calves were recorded. Due to the randomness of calf sex, other dam-bull calf pairs had to be selected from a reserve of extra breeding herds that are maintained on experiment station property, not all necessarily located at the Tifton, Georgia campus. A total of 38 sires were eventually involved over the five years. New bulls were chosen each year, but in a few instances, a bull had to be used a second year to provide enough calves. After weaning each year, one half of the bull calves [12, 3 from each breed - genetic potential group] from BW-WP and BW-CP were randomly assigned (see Figure 1) to a feedlot (F), while the other half (12) from BW-WP and BW-CP were assigned to summer pasture (SP) during the post-weaning phase (AW) which consisted of a 21-day adjustment period followed by 168 days on the assigned treatment. Body weight, height, and scrotal circumference were measured at weaning, at 21 days, and every 28 days after that until the 189-day AW phase was completed. The young bulls assigned to the summer pasture were kept an additional 140 days to evaluate their continued performance where the 
previously described measurements continued at 28-day intervals. Those bulls assigned to the feedlot were incorporated into the station's pool of breeding sires or sold at auction. At each time of measurement, all the bulls were ranked on calculated average daily gain $(A D G)$ through that measurement period from highest to lowest $A D G$. All bulls having the same ADG (ties) received the average of the ranks involved [if four were tied and their ranks were 159-162, then the assigned rank to all four would be $0.25 \mathrm{x}$ $(159+160+161+162)=160.5]$. Change in rank was defined as the absolute value of the change in ranking to the next measurement period from the initial 21-DAW (days after weaning) measurement. The size of the change was more important than the direction the change. Use of ranks as a transformation on $\mathrm{ADG}$ data destroys information about variation between $\mathrm{ADG}$ values for two different bull calves, and some of intra-correlation between successive measurements on the same bull calf. Two bull calves were removed due to health reasons (one with an obvious limp which would prevent successful breeding and another with a broken leg) and their data was removed from the final data set.

The data were analyzed using Proc GLM [Ver. 6] (SAS, 1989) and Proc MIXED [Ver. $7 \&$ 8] (SAS, 2000). The mixed model used to describe the study appears in Table 3. Since each year started with a new set of 48 dam-bull calf pairs, years were considered as blocks and therefore represented a random effect. Repeated measures were used on the data for change in rank for $\mathrm{ADG}$. The interaction of most interest was genetic potential (Line) by pre-weaning treatment by post-weaning treatment. It was believed the two breeds selected would behave similarly since both are British breeds.

\section{RESULTS AND DISCUSSION}

Simple statistics for body weight, hip height, and scrotal circumference from birth through weaning are presented in Table A 1 . Simple statistics for body weight, hip height, and scrotal circumference from weaning through the end of the study are presented in Table A2. Simple statistics for each year for various measured variables of interest from birth through the end of the study are presented in Table A3.

Least square means from the analysis of the data are shown in Table 2. Preweaning treatment did cause a slight effect difference in average daily gains (ADG) at the time of weaning which is understandable. Genetic performance level produced a slight difference in ADG which is understandable. After all, these young bulls from better genetic sires should do better. What was not anticipated was the small effect difference associated with the Angus breed. However, by distributing the young bulls between the two post-weaning treatments, both breed and pre-weaning differences were erased. The better genetic bred young bulls expanded their performance difference by the end of the 189-day post-weaning treatment period. As expected there was a large difference between the grain concentrate-fed bulls compared with those on summer pasture. Examination of the ranked $A D G$ values revealed about the same results as was evidenced with the actual $A D G$ values at weaning. The end of the post-weaning treatment period also mirrored the ADG results. Surprisingly, the ending net change in ranked ADG values shows relatively few differences between any of the main effects. Weaned bull calves were randomly distributed by breed, genetic performance, and pre-weaning 
treatment levels into post-weaning treatments each year. The significant effects are forced to appear in the interactions with post-weaning treatment levels which was the original intent of the study

Table 3 contains the results of the analysis of variance using Proc MIXED (SAS, 2000). A random effects model was used to analyze the data. ADG and ranked ADG resulted in similar analyses. Some of the random effect terms were found to be zero using the full model, these terms were removed from the full model resulting in the reduced model. The estimated variance components for year by pre-weaning treatmentand sires within year and pre-weaning treatment, former is a source of error for pre-weaning treatment, were both found to be zero. The last three fixed effect interactions were found to be highly non-significant and are excluded in the reduced model. The results of the analysis suggest that breed $(\boldsymbol{P}<0.05)$, genetic performance level $(\boldsymbol{P}<0.01)$, pre-weaning $(\boldsymbol{P}<0.01)$, post-weaning $(\boldsymbol{P}<0.0001)$, and time of measurement effects $(\boldsymbol{P}<0.01)$ were significant. Breed by time of measurement $(\boldsymbol{P}<0.01)$, genetic performance level by time of measurement $(\boldsymbol{P}<0.10)$, breed by genetic performance level by time of measurement $(\boldsymbol{P}<0.05)$, pre-weaning treatment by time of measurement $(\boldsymbol{P}<0.01)$, post-weaning treatment by time of measurement $(\boldsymbol{P}<0.0001)$, breed by pre-weaning by post-weaning by time of measurement $(\boldsymbol{P}<0.05)$, and genetic performance level by pre-weaning by postweaning by time of measurement $(\boldsymbol{P}<0.01)$ interactions also were significant.

The analysis of variance for change in rank for $\mathrm{ADG}$ revealed that only one main effect was significant $(\boldsymbol{P}<0.0001)$ which was time of measurement. Genetic performance level by post-weaning treatment $(\boldsymbol{P}<0.05)$, pre-weaning treatment by post-weaning treatment $(\boldsymbol{P}<0.10)$, pre-weaning treatment by post-weaning treatment by time of measurement $(\boldsymbol{P}<0.05)$, and breed by genetic performance level by pre-weaning treatment by post-weaning treatment by time of measurement $(\boldsymbol{P}<0.05)$ interactions were significant. Absolute value of the change in rank of ADG was of interest since this was indicative of efficacy of the treatment groups. Bulls with higher ADG earlier in the trial period will tend to have lower $\mathrm{ADG}$ later in the trial period since there is an increasing competition for resources between continued growth and maintenance of the body (feed efficiency) within the animal. Bulls that have lower ADG earlier will continue to increase their ADG until the competition for resources between continued growth and maintenance needs causes a decrease in feed efficiency.

Table 4 (Angus breed) shows the estimates of regression coefficients between time of measurement and rank for ADG within the eight treatment groups from the factorial consisting of genetic performance level by pre-weaning treatment level by postweaning treatment level from the analysis of variance involving the Angus and Hereford bulls. Although the difference between the high and low genetic performance levels for either the feedlot or summer pasture is not significant, the difference for pre-weaning treatment of creep-fed plus winter pasture is greater than the comparable difference for winter pasture only. What is striking are the huge significant differences between the post-weaning treatments of feedlot bulls fed grain concentrate compared with summer pasture of the intercepts. The intercept is at mean time of measurement (91.875). Draper and Smith (1981) recommend conducting regression analysis this way. The linear and quadratic regression coefficients also are significantly different between the two post- 
weaning treatments. Generally, the Angus bulls assigned to the feedlot improved their $A D G$ values (lower rank value, best $=1$ ). In the southeastern Coastal Plain, those bulls coming out of the winter pasture only pre-weaning treatment improved ADG values more than did those coming from the creep-fed plus winter pasture. Some beef cattle operations calve during the winter so high growth rates can be accomplished with the spring pastures where forage is plentiful and usually of higher quality. But growth cannot continue forever since more and more energy from the diet will be diverted to maintain the existing bulk of the bull, therefore the peak ranking occurred between 88.95 and 163.61 days after weaning (DAW). As expected, the high genetic performance bulls achieved relative peak $A D G$ later than did the low genetic performance bulls. This is also expected since the genetic performance level of the bull is extremely important in achieving the desired weight gains. The reverse phenomenon is also true. Those Angus bulls placed on summer pasture had their ranking of $\mathrm{ADG}$ to become worse (ranking of $\mathrm{ADG}$ values are increasing). During the pre-weaning treatment phase, the bull calf can supplement the effects of poorer quality forage by nursing their mother. However, when moved from this environment to summer pasture, the bull calf usually has an adjustment period before the effects of less nutrition can be overcome. The ADG falls from a high level (good nutrition from mother's milk) until the ADG level hits the nutrition level of the forage in the summer pasture. Therefore, the valley of ranking of ADG occurred between 122.96 and 166.04 DAW. Although a much narrower range, it appears that it takes about as long to overcome switching from a good nutritious diet to a poorer quality diet, as it does for the better quality diet of grain concentrate in the feedlot to discontinue high ADG. Figures $2 \mathrm{a}$ and $2 \mathrm{~b}$ illustrates using the changes in ranking of ADG data how the bull calves performed. A bigger range of change in ranking of $A D G$ value occurred with the feedlot Angus bulls than with the summer pasture bulls, even though change in ranking of $\mathrm{ADG}$ value finally narrowed to less than 25 from a beginning high of 45 to 85 .

Table 5 (Hereford breed) shows the estimates of regression coefficients between time of measurement and rank for $\mathrm{ADG}$ within the eight treatment groups from the factorial consisting of genetic performance level by pre-weaning treatment level by postweaning treatment level from the analysis of variance involving the Angus and Hereford bulls. Although the difference between the high and low genetic performance levels for either the feedlot or summer pasture is not significant, the difference for pre-weaning treatment of creep-fed plus winter pasture is greater than the comparable difference for winter pasture only. What is striking are the huge significant differences between the post-weaning treatments of feedlot bulls fed grain concentrate compared with summer pasture of the intercepts. The intercept is at mean time of measurement (91.875 DAW). The linear and quadratic regression coefficients show a huge significantly different effect between the two post-weaning treatments. Generally, the Hereford bulls assigned to the feedlot improved their ADG values. Those bulls coming out of the winter pasture only pre-weaning treatment improved $A D G$ values more than did those coming from the creep-fed plus winter pasture. But growth cannot continue forever since more and more energy from the diet will be diverted to maintain the existing bulk of the bull, therefore the peak ranking of $A D G$ occurred between 110.51 and 164.79 DAW. As expected, the high genetic performance bulls achieved relative peak ADG later than did the low genetic 
performance bulls. This is also expected since the genetic performance level of the bull is extremely important in achieving the desired weight gains. The reverse phenomenon is also true. Those Hereford bulls placed on summer pasture had their ranking of ADG values to become worse (ranking of $\mathrm{ADG}$ values are increasing). During the pre-weaning treatment phase, the bull calf can supplement the effects of poorer quality forage by nursing their mother. However, when moved from this environment to summer pasture, the bull calf usually has an adjustment period before the effects of less nutrition can be overcome. The ADG falls from a high level until the $\mathrm{ADG}$ level hits the nutrition level of the forage in the summer pasture. Therefore, the valley of ranking of ADG values occurred between 79.04 and 140.55 DAW. Although a much wider range, it appears that it takes slightly less time to overcome switching from a good nutritious diet to a poorer quality diet, as it does for the better quality diet of grain concentrate in the feedlot to discontinue high $\mathrm{ADG}$. Figures $3 \mathrm{a}$ and $3 \mathrm{~b}$ illustrates using the change in ranking of $\mathrm{ADG}$ data how the bull calves performed. A bigger range of change in ranking of ADG values occurred with the feedlot Hereford bulls than with the summer pasture bulls, even though change in ranking of $\mathrm{ADG}$ values finally narrowed to less than 20 from a beginning high of 45 to 75 .

\section{CONCLUSIONS}

Could pre-weaning preparation and/or post-weaning finishing ever supplant the importance of a bull calf's genetic performance of his sire? Results demonstrate that the type of post-weaning finishing can negate any genetic performance advantage the bu11 calf has. In fact, examining the higher order interactions suggests that any negative effects that any poor pre-weaning preparation the bull calf might receive can be negated completely by the type of post-weaning finishing received. This research was done in an orderly fashion with relatively few bull calves in any post-weaning setting compared to typical commercial feedlot operations where thousands of steers are finished each year. However, young bulls are significantly more competitive than are steers. And this competitiveness increases dramatically in intensity if there are cows in estrus with them. It can be concluded that a high energy feeding system in a bull test station could for all practical purposes transform a bull calf with either poor environmental and/or genetic performance preparation into a bull with superior ADG. 


\section{REFERENCES}

Draper, N. R. and H. Smith. 1981. Applied regression analysis ( $2^{\text {nd }}$ ed.). New York City: Wiley.

Drouillard, J. S. and G. L. Kuhl. 1999. Effects of previous grazing nutrition and management on feedlot performance of cattle. J. Animal Science 77(Suppl 2):136146.

Holland, M. D. and K. G. Odde. 1992. Factors affecting calf birth weight: A review. Theriogenology 38:769-798.

Janloo, S., H. G. Dolezal, F. N. Owens and A. La Manna. 1998. Impact of withholding feed on weight and composition of ruminal contents of feedlot cattle. I. Animal Science 76(Supp1 1):299. (Abs. \#1167)

Jordon, D. J., T. J. Klopfenstein, C. T. Milton, G. E. Erickson and R. J. Cooper. 1998. Evaluation of compensatory gain and grazing systems for yearling cattle. J. Animal Science 76(Suppl 1):329. (Abs. \#1290)

Klopfenstein, T., R. Cooper, D. J. Jordon, D. Shain, T. Milton, C. Calkins and C. Rossi. 2000. Effects of backgrounding and growing programs on beef carcass quality and yield. Proceedings of the American Society of Animal Science, July 21-23, 1999 , Indianapolis, IN, pp 1-11.

Pordomingo, A. J., N. A. Juan and R. Jouli. 1998. Weaning age and feeding strategy on calf performance. J. Animal Science 76(Suppl 1):324. (Abs. \#1269)

Pritchard, R. H. 1998. Feeding management for beef cattle. J. Animal Science 76(Supp1 1):307. (Abs. \#1199)

Robison, O. W. 1981. The influence of maternal effects on the efficiency of selection: A review. Livestock Production Science 8:121-137.

Spillman, A. 2003. Well-rounded bulls bring profit to cattle breeders. Agricultural Research 51(4):12-13.

Weakley, D. C. and L. F. Reutzel. 1998. Assessment of feeding management practices for beef and dairy cattle: Historical perspectives and application of research on feeding management. . J. Animal Science 76(Suppl 1):306. (Abs. \#1198) 
Table 1. Sample sizes by year, breed, genetic performance level, pre-weaning treatment, and post-weaning treatment of cow-calf pairs (before weaning) and young bulls (after weaning) at Tifton, Georgia.

\begin{tabular}{|c|c|c|}
\hline Sampling Effect & Class Level & Sample Size \\
\hline & 1985 & 47 \\
\multirow{2}{*}{ Year } & 1986 & 48 \\
& 1987 & 48 \\
& 1988 & 48 \\
& 1989 & 48 \\
\hline \multirow{2}{*}{ Breed } & Angus & 119 \\
& Hereford & 120 \\
\hline \multirow{2}{*}{ Genetic Performance Level } & High & 119 \\
\hline \multirow{2}{*}{ Pre-Weaning Treatment } & Low & 125 \\
\hline \multirow{2}{*}{ Post-Weaning Treatment } & Grain Concentrate (Feedlot) & 114 \\
\hline
\end{tabular}

Notes: Although 240 cow-calf pairs were originally planned, one calf became sick and had to be removed before the weaning phase was completed. Two more young bulls had to be removed before the end of the 189-day post weaning study (one was limping, one had a broken leg). Two more young bulls had to be removed before the end of the 329-day study due to injuries suffered in the pasture. Numbers listed above are for those young bulls present at weaning. Genetic performance level applies to the sire of the calf. It was determined by ranking the sires when they were calves. The highest ranking five to eight young bulls each year were identified as high performance (ranking of ADG + WDA [weight per day of age]), while the five to eight lowest ranking bulls were identified as low performance. 
Table 2. Means for beginning and ending of post-weaning treatment phase for breed, genetic performance level, pre-weaning treatment, and post-weaning treatment for bulls at Tifton, Georgia from the calving seasons in 1985-1989.

\begin{tabular}{|c|c|c|c|c|c|c|c|}
\hline \multirow{2}{*}{$\begin{array}{l}\text { Sampling } \\
\text { Effect }\end{array}$} & \multirow{2}{*}{ Effect Level } & \multicolumn{2}{|c|}{$\mathrm{ADG}$} & \multicolumn{2}{|c|}{$\mathrm{rADG}$} & \multicolumn{2}{|c|}{ rcADG } \\
\hline & & Initial & Ending & Initial & Ending & Initial & Ending \\
\hline \multirow{2}{*}{ Breed } & Angus & 0.95 & 1.02 & 99.4 & 119.9 & 68.3 & 12.7 \\
\hline & Hereford & 0.86 & 1.03 & 140.4 & 120.1 & 67.2 & 10.4 \\
\hline \multirow{2}{*}{$\begin{array}{c}\text { Genetic } \\
\text { Performance } \\
\text { Level }\end{array}$} & High & 0.95 & 1.07 & 96.6 & 108.9 & 69.5 & 11.0 \\
\hline & Low & 0.86 & 0.98 & 143.2 & 131.0 & 66.0 & 12.2 \\
\hline \multirow{2}{*}{$\begin{array}{l}\text { Pre-Weaning } \\
\text { Treatment }\end{array}$} & $\begin{array}{c}\text { Creep-Fed + } \\
\text { Winter } \\
\text { Pasture }\end{array}$ & 0.95 & 1.02 & 96.1 & 120.3 & 64.4 & 12.2 \\
\hline & $\begin{array}{l}\text { Winter } \\
\text { Pasture }\end{array}$ & 0.86 & 1.03 & 146.2 & 119.6 & 71.1 & 10.9 \\
\hline \multirow{2}{*}{$\begin{array}{c}\text { Post- } \\
\text { Weaning } \\
\text { Treatment }\end{array}$} & $\begin{array}{c}\text { Grain } \\
\text { Concentrate }\end{array}$ & 0.90 & 1.33 & 121.3 & 59.7 & 65.2 & 11.9 \\
\hline & $\begin{array}{l}\text { Summer } \\
\text { Pasture }\end{array}$ & 0.91 & 0.73 & 118.7 & 178.8 & 70.3 & 11.3 \\
\hline
\end{tabular}

Notes: Creep-fed contains concentrate for calves and are designed to keep adult cows from entering the feeder equipment. $\mathrm{ADG}=$ Average Daily Gain (lbs day ${ }^{-1}$ ). $\mathrm{rADG}=$ ranked $\mathrm{ADG}$ (highest $=1$, lowest $=239$ ). $\mathrm{rcADG}=$ rank change in $\mathrm{ADG}$ over the 168 day evaluation period (base = weaning ADG) (21 DAW through 189 $\mathrm{DAW}$ ) [each evaluation period (absolute value of weaning ranked ADG - period ranked $A D G)]$. During the 168 day evaluation, two bulls had to be removed for health reasons (one in 1988 and in 1989, one broke his leg, one came up limping). Genetic performance level applies to the sire of the calf. It was determined by ranking the sires when they were calves. The highest ranking five to eight young bulls each year were identified as high performance (ranking of ADG + WDA [weight per day of age]), while the five to eight lowest ranking bulls were identified as low performance. 
Table 3. Analysis of variance for average daily gain (ADG), ranked ADG, and change in ranked ADG with $\mathrm{F}$ and/or $\mathrm{Z}$ values from Proc MIXED (SAS, 2000) using a reduced model of 239 bull calves from a five-year experiment (1985-1989) at CPES in Tifton, Georgia.

\begin{tabular}{|c|c|c|c|c|c|c|c|}
\hline \multirow{2}{*}{ Source of Variation } & \multirow{2}{*}{$\begin{array}{l}\text { Effect } \\
\text { Status }\end{array}$} & \multicolumn{2}{|c|}{$\operatorname{ADG}\left(1 \mathrm{bs}\right.$ day $\left.^{-1}\right)$} & \multicolumn{2}{|c|}{ Ranked ADG } & \multicolumn{2}{|c|}{ Change in Ranked ADG (abs val) } \\
\hline & & $\mathrm{df}$ & $F / Z$ & df & $\mathrm{F} / \mathrm{Z}$ & $\mathrm{df}$ & $\mathrm{F} / \mathrm{Z}$ \\
\hline Year $(Y)$ & $\mathrm{R}$ & 4 & $2.10 \mathrm{e}-04$ & 4 & 0.00 & 4 & 5.73 \\
\hline Breed (B) & $\mathrm{F}$ & 1 & $5.79 *$ & 1 & $7.46^{*}$ & 1 & 0.08 \\
\hline Line (L) & $\mathrm{F}$ & 1 & $10.29 * *$ & 1 & $14.85^{*}$ & 1 & 0.01 \\
\hline $\mathrm{B} \times \mathrm{L}$ & $\mathrm{F}$ & 1 & 0 & 1 & 0.13 & 1 & 1.76 \\
\hline$Y \times B \times L$ & $\mathrm{R}$ & 12 & $3.08 \mathrm{e}-03$ & 12 & 89.86 & - & - \\
\hline Sire (Y B L) & $\mathrm{R}$ & 19 & $1.54 \mathrm{e}-03$ & 19 & 19.75 & - & - \\
\hline Pre-Weaning Trt (BW) & $\mathrm{F}$ & 1 & $7.53 * *$ & 1 & $8.60 * *$ & 1 & 0.26 \\
\hline $\mathrm{B} \times \mathrm{BW}$ & $\mathrm{F}$ & 1 & 0.13 & 1 & 0.13 & 1 & 0.56 \\
\hline $\mathrm{L} \times \mathrm{BW}$ & $\mathrm{F}$ & 1 & 0.05 & 1 & 0.11 & 1 & 0.02 \\
\hline $\mathrm{B} \times \mathrm{L} \times \mathrm{BW}$ & $\mathrm{F}$ & 1 & 0.12 & 1 & 0.08 & 1 & 0.07 \\
\hline $\mathrm{Y} \times \mathrm{B} \times \mathrm{L} \times \mathrm{BW}$ & $\mathrm{R}$ & - & - & - & - & - & - \\
\hline Sire (Y B L BW) & $\mathrm{R}$ & - & - & - & - & - & - \\
\hline Post-Weaning Trt (AW) & $\mathrm{F}$ & 1 & $507.06^{* *}$ & 1 & $410.20 * *$ & 1 & 2.02 \\
\hline $\mathrm{B} \times \mathrm{AW}$ & $\mathrm{F}$ & 1 & 0.90 & 1 & 1.12 & 1 & 2.76 \\
\hline $\mathrm{L} \times \mathrm{AW}$ & $\mathrm{F}$ & 1 & 1.61 & 1 & 0.60 & 1 & $5.49 *$ \\
\hline$B \times L \times A W$ & $\mathrm{~F}$ & 1 & 0.07 & 1 & 0.33 & 1 & 0.90 \\
\hline $\mathrm{BW} \times \mathrm{AW}$ & $\mathrm{F}$ & 1 & 0.04 & 1 & 0.00 & 1 & 2.76 \\
\hline$B \times B W \times A W$ & $\mathrm{~F}$ & 1 & 1.36 & 1 & 0.49 & 1 & 0.50 \\
\hline $\mathrm{L} \times \mathrm{BW} \times \mathrm{AW}$ & $\mathrm{F}$ & 1 & 0.01 & 1 & 0.07 & 1 & 0.06 \\
\hline $\mathrm{B} \times \mathrm{L} \times \mathrm{BW} \times \mathrm{AW}$ & $\mathrm{F}$ & 1 & 0.01 & 1 & 0.03 & 1 & 0.60 \\
\hline$Y \times B \times L \times B W \times A W$ & $\mathrm{R}$ & 38 & $3.10 \mathrm{e}-3+$ & 38 & $149.18^{*}$ & - & - \\
\hline Sire (Y B L BW AW) & $\mathrm{R}$ & - & - & - & - & 97 & 6.65 \\
\hline Calf (Y B L S BW AW) & $\mathrm{R}$ & 150 & $1.80 \mathrm{e}-2 * *$ & 150 & $509.58 * *$ & 122 & -0.00466 \\
\hline
\end{tabular}

Table 3 continued on next page. 
Table 3 continued from previous page.

\begin{tabular}{|c|c|c|c|c|c|c|c|}
\hline \multirow{2}{*}{ Source of Variation } & \multirow{2}{*}{$\begin{array}{l}\text { Effect } \\
\text { Status }\end{array}$} & \multicolumn{2}{|c|}{ ADG (lbs day $\left.{ }^{-1}\right)$} & \multicolumn{2}{|c|}{ Ranked ADG } & \multicolumn{2}{|c|}{ Change in Ranked ADG (abs val) } \\
\hline & & df & $\mathrm{F} / \mathrm{Z}$ & df & $\mathrm{F} / \mathrm{Z}$ & $\mathrm{df}$ & $\mathrm{F} / \mathrm{Z}$ \\
\hline Time of Measure (T) & $\mathrm{F}$ & 7 & $3.93 * *$ & 7 & 0.01 & 6 & $62.08 * *$ \\
\hline $\mathrm{Y} \times \mathrm{T}$ & $R$ & 28 & $9.14 \mathrm{e}-3 * *$ & 28 & $287.31 * *$ & 24 & $14.67+$ \\
\hline $\mathrm{B} \times \mathrm{T}$ & $\mathrm{F}$ & 7 & $9.60 * *$ & 7 & $11.72 * *$ & 6 & 0.16 \\
\hline $\mathrm{L} \times \mathrm{T}$ & $\mathrm{F}$ & 7 & $1.80+$ & 7 & $2.07 *$ & 6 & 0.67 \\
\hline$B \times L \times T$ & $\mathrm{~F}$ & 7 & $2.34 *$ & 7 & $1.99+$ & 6 & 0.42 \\
\hline $\mathrm{BW} \times \mathrm{T}$ & $\mathrm{F}$ & 7 & $13.89 * *$ & 7 & $19.21 * *$ & 6 & 1.09 \\
\hline $\mathrm{B} \times \mathrm{BW} \times \mathrm{T}$ & $\mathrm{F}$ & 7 & 0.14 & 7 & 0.60 & 6 & 0.60 \\
\hline $\mathrm{L} \times \mathrm{BW} \times \mathrm{T}$ & $\mathrm{F}$ & 7 & 0.24 & 7 & 0.53 & 6 & 0.65 \\
\hline$B \times L \times B W \times T$ & $\mathrm{~F}$ & - & & - & - & 6 & 1.05 \\
\hline$\Delta \mathrm{W} \times \mathrm{T}$ & $\mathrm{F}$ & 7 & $74.39 * *$ & 7 & $82.54 * *$ & 6 & 0.40 \\
\hline $\mathrm{B} \times \mathrm{AW} \times \mathrm{T}$ & $\mathrm{F}$ & 7 & 0.28 & 7 & 0.22 & 6 & 0.50 \\
\hline $\mathrm{L} \times \mathrm{AW} \times \mathrm{T}$ & $\mathrm{F}$ & 7 & 0.27 & 7 & 0.42 & 6 & 1.18 \\
\hline$B \times L \times A W \times T$ & $\mathrm{~F}$ & - & - & - & - & 6 & 0.45 \\
\hline $\mathrm{BW} \times \mathrm{AW} \times \mathrm{T}$ & $\mathrm{F}$ & 7 & 0.96 & 7 & 0.46 & 6 & $2.42 *$ \\
\hline$B \times B W \times A W \times T$ & $\mathrm{~F}$ & 7 & $2.63^{*}$ & 7 & $2.59^{*}$ & 6 & 0.21 \\
\hline $\mathrm{L} \times \mathrm{BW} \times \mathrm{AW} \times \mathrm{T}$ & $\mathrm{F}$ & 7 & $3.29^{* *}$ & 7 & $2.76^{* *}$ & 6 & 0.11 \\
\hline $\mathrm{B} \times \mathrm{L} \times \mathrm{BW} \times \mathrm{AW} \times \mathrm{T}$ & $\mathrm{F}$ & - & - & - & - & 6 & $2.18^{*}$ \\
\hline$Y \times B \times L \times B W \times A W \times T$ & $\mathrm{R}$ & 371 & $4.67 e-3^{* *}$ & 371 & $101.13^{* *}$ & 300 & $75.26^{* *}$ \\
\hline Residual Error & $\mathrm{R}$ & 1178 & $2.81 \mathrm{e}-2 * *$ & 1178 & $865.45 * *$ & 1009 & $587.53 * *$ \\
\hline
\end{tabular}

Notes: The first page of the table involves the 239 young bulls, each as a block of post-weaning measurements, and the second page involves the measurements. In the effect status column, $\mathrm{R}$ denotes this effect is random, while $\mathrm{F}$ denotes this effect is fixed for the Proc MIXED analysis only. In the F/Z columns, F designates the value is the F-test (fixed effect), while $Z$ designates the value is the Z-test (random effect). ${ }^{+},{ }^{*},{ }^{*} *$ denote the levels of significance of $\boldsymbol{P}<0.10, \boldsymbol{P}<0.05$, and $\boldsymbol{P}<0.01$, respectively. Unsuperscripted values are not significant at $\boldsymbol{P}>0.10$. Cells containing a hyphen (-) are effects that were removed from the complete model to give the reduced model shown in the table. Line $=$ Genetic performance. 
Table 4. Regression coefficients for high and low genetic performance levels by creep-fed + winter pasture and winter pasture only treatments on ranked post-weaning average daily gain over 189 days of Angus bulls fed grain concentrate in a feedlot or grazing on summer pasture at CPES located in Tifton, Georgia from data collected during the 1985-1989 calving season.

\begin{tabular}{|c|c|c|c|c|c|c|}
\hline $\begin{array}{c}\text { Genetic Performance } \\
\text { Level }\end{array}$ & $\begin{array}{l}\text { Pre-Weaning } \\
\text { Treatment }\end{array}$ & $\begin{array}{l}\text { Post-Weaning } \\
\text { Treatment }\end{array}$ & Intercept & Linear & Quadratic & Calculus \\
\hline \multirow{4}{*}{ High } & \multirow{2}{*}{$\begin{array}{c}\text { Creep-Fed + Winter } \\
\text { Pasture }\end{array}$} & Feedlot & 40.16 & -0.12 & $+1.16 \mathrm{e}-3$ & 143.60 \\
\hline & & Summer Pasture & $152.96 * *$ & $+0.58 * *$ & $-3.91 \mathrm{e}-3^{* *}$ & 166.04 \\
\hline & \multirow{2}{*}{ Winter Pasture } & Feedlot & 47.74 & -0.33 & $+2.30 \mathrm{e}-3$ & 163.61 \\
\hline & & Summer Pasture & $167.08 * *$ & $+0.23 * *$ & $-3.70 \mathrm{e}-3^{* *}$ & 122.96 \\
\hline \multirow{5}{*}{ Low } & \multirow{2}{*}{$\begin{array}{c}\text { Creep-Fed + Winter } \\
\text { Pasture }\end{array}$} & Feedlot & 74.04 & +0.01 & $+1.71 \mathrm{e}-3$ & 88.95 \\
\hline & & Summer Pasture & $169.73 * *$ & $+0.38 * *$ & $-2.63 \mathrm{e}-3^{* * *}$ & 164.12 \\
\hline & \multirow{2}{*}{ Winter Pasture } & Feedlot & 67.43 & -0.23 & $+4.75 \mathrm{e}-3$ & 116.09 \\
\hline & & Summer Pasture & $179.78 * *$ & $+0.25 * *$ & $-2.05 \mathrm{e}-3^{* *}$ & 152.85 \\
\hline & & Standard Error & 17.67 & 0.046 & $8.56 \mathrm{e}-4$ & \\
\hline
\end{tabular}

Notes: Genetic performance level applies to the sire of the calf. It was determined by ranking the sires when they were calves. The highest ranked five to eight young bulls each year were identified as high performance (ranking of ADG + WDA [weight per day of age]), while the five to eight lowest ranked bulls were identified as low performance. Due to unequal numbers in each treatment group, the standard error given for each regression coefficient is a weighted average of all sixteen individual standard errors. Intercept and linear coefficients were determined at $\mathrm{x}$ where $\mathrm{x}=(\mathrm{X}-\mathrm{Xbar})$ and $\mathrm{X}$ are the times when the measurements were made during the 189-day post-weaning part of the study (Xbar $=91.875$, [mean of $0,21,49,77,105,133,161,189])$. The values in the calculus column have been adjusted to reflect the true time of measurement. ${ }^{* *}$ deñotes significance of $\boldsymbol{P}<0.01$ and indicates that this coefficient is significantly different from the coefficient immediately above it. Thus, the summer pasture post-weaning treatment was always different from the feedlot post-weaning treatment. 
Table 5. Regression coefficients for high and low genetic performance levels by creep-fed + winter pasture and winter pasture only treatments on ranked post-weaning average daily gain over 189 days of Hereford bulls fed grain concentrate in a feedlot or grazing on summer pasture at CPES located in Tifton, Georgia from data collected during the 1985-1989 calving season.

\begin{tabular}{|c|c|c|c|c|c|c|}
\hline $\begin{array}{c}\text { Genetic Performance } \\
\text { Level }\end{array}$ & $\begin{array}{l}\text { Pre-Weaning } \\
\text { Treatment }\end{array}$ & $\begin{array}{l}\text { Post-Weaning } \\
\text { Treatment }\end{array}$ & Intercept & Linear & Quadratic & Calculus \\
\hline \multirow{4}{*}{ High } & \multirow{2}{*}{$\begin{array}{c}\text { Creep-Fed Winter } \\
\text { Pasture }\end{array}$} & Feedlot & 44.66 & -0.12 & $+3.22 \mathrm{e}-3$ & 110.51 \\
\hline & & Summer Pasture & $179.26^{* *}$ & $+0.38 * *$ & $-5.05 \mathrm{e}-3^{* *}$ & 129.50 \\
\hline & \multirow{2}{*}{ Winter Pasture } & Feedlot & 66.41 & -0.49 & $+4.04 \mathrm{e}-3$ & 152.52 \\
\hline & & Summer Pasture & $178.91 * *$ & $-0.038 * *$ & $-1.48 \mathrm{e}-3^{* *}$ & 79.04 \\
\hline \multirow{5}{*}{ Low } & \multirow{2}{*}{$\begin{array}{c}\text { Creep-Fed Winter } \\
\text { Pasture }\end{array}$} & Feedlot & 79.16 & -0.30 & $+3.08 \mathrm{e}-3$ & 140.58 \\
\hline & & Summer Pasture & $199.39 * *$ & $+0.08 * *$ & $-4.24 \mathrm{e}-3^{* *}$ & 101.31 \\
\hline & \multirow{2}{*}{ Winter Pasture } & Feedlot & 77.79 & -0.63 & $+4.32 \mathrm{e}-3$ & 164.79 \\
\hline & & Summer Pasture & $196.13^{* * *}$ & $+0.11 * *$ & $-1.13 e-3^{* *}$ & 140.55 \\
\hline & & Standard Error & 17.67 & 0.046 & $8.56 \mathrm{e}-4$ & \\
\hline
\end{tabular}

Notes: Genetic performance level applies to the sire of the calf. It was determined by ranking the sires when they were calves.

The highest ranked five to eight young bulls each year were identified as high performance (ranking of ADG + WDA [weight per day of age]), while the five to eight lowest ranked bulls were identified as low performance. Due to unequal numbers in each treatment group, the standard error given for each regression coefficient is a weighted average of all sixteen individual standard errors. Intercept and linear coefficients were determined at $\mathrm{x}$ where $\mathrm{x}=(\mathrm{X}-\mathrm{Xbar})$ and $\mathrm{X}$ are the times when the measurements were made during the 189-day post-weaning part of the study (Xbar $=91.875$, [mean of $0,21,49,77,105,133,161,189])$. The values in the calculus column have been adjusted to reflect the true time of measurement. $* *$ denotes significance of $\boldsymbol{P}<0.01$ and indicates that this coefficient is significantly different from the coefficient immediately above it. Thus, the summer pasture post-weaning treatment was always different from the feedlot post-weaning treatment. 
Table A1. Simple statistics describing the 239 bill calves over a five-year period (1985-1989) involving two British breeds of beef cattle, two sire genetic performance levels, and two pre-weaning treatments measured over the period from birth to weaning at Tifton, Georgia.

\begin{tabular}{|c|c|c|c|c|c|c|c|c|c|c|}
\hline \multirow{2}{*}{$\begin{array}{l}\text { Beef } \\
\text { Breed }\end{array}$} & \multirow{2}{*}{$\begin{array}{l}\text { Sire Genetic } \\
\text { Performance }\end{array}$} & \multirow{2}{*}{$\begin{array}{c}\text { Pre-Weaning } \\
\text { Treatment }\end{array}$} & \multicolumn{3}{|c|}{ Birth } & \multicolumn{5}{|c|}{ Weaning } \\
\hline & & & $\mathrm{N}$ & $\begin{array}{l}\text { Date } \\
\text { (JD) }\end{array}$ & $\begin{array}{l}\text { Weight } \\
(\mathrm{kg})\end{array}$ & Age (d) & $\begin{array}{l}\text { Weight } \\
(\mathrm{kg})\end{array}$ & $\begin{array}{l}\text { Hip Ht } \\
\text { (cm) }\end{array}$ & $\mathrm{N}$ & $\begin{array}{c}\text { Scrotal } \\
\text { Circ (cm) }\end{array}$ \\
\hline \multirow{4}{*}{ Angus } & \multirow{2}{*}{ High } & Creep-Fed+WP & 35 & $342(19)$ & $34.3(5)$ & $232(19)$ & $273(32)$ & $111(4)$ & 35 & $23.0(3.1)$ \\
\hline & & Winter Pasture (WP) & 24 & $348(13)$ & $34.5(5)$ & $236(12)$ & $261(25)$ & $111(3)$ & 24 & $23.7(2.6)$ \\
\hline & \multirow{2}{*}{ Low } & Creep-Fed+WP & 24 & $337(18)$ & $32.6(5)$ & $225(18)$ & $245(27)$ & $108(3)$ & 24 & $23.3(3.2)$ \\
\hline & & Winter Pasture (WP) & 36 & $342(16)$ & $32.6(4)$ & $232(16)$ & $233(27)$ & $106(4)$ & 34 & $22.4(3.0)$ \\
\hline \multirow{4}{*}{ Hereford } & \multirow{2}{*}{ High } & Creep-Fed+WP & 36 & $337(19)$ & $37.8(5)$ & $226(19)$ & $255(34)$ & $110(4)$ & 36 & $23.0(3.0)$ \\
\hline & & Winter Pasture (WP) & 24 & $338(21)$ & $37.4(5)$ & $226(20)$ & $226(21)$ & $109(3)$ & 24 & $21.7(2.9)$ \\
\hline & \multirow{2}{*}{ Low } & Creep-Fed +WP & 30 & $338(17)$ & $33.7(5)$ & $226(17)$ & $227(38)$ & $107(4)$ & 30 & $21.2(2.7)$ \\
\hline & & Winter Pasture (WP) & 30 & $342(13)$ & $34.4(4)$ & $232(12)$ & $215(33)$ & $106(3)$ & 30 & $21.0(2.5)$ \\
\hline
\end{tabular}

Notes: Genetic performance level applies to the sire of the calf. It was determined by ranking the sires when they were calves. The highest ranked five to eight young bulls each year were identified as high performance (ranking of ADG + WDA

[weight per day of age]), while the five to eight lowest ranked bulls were identified as low performance. JD = Julian day. Circ $=$ Circumference. Number in parenthesis is the standard deviation. 
Table A2. Simple statistics describing the 239 bill calves over a five-year period (1985-1989) involving two British breeds of beef cattle, two sire genetic performance levels, and two pre-weaning treatments measured over the period from weaning to end of study at Tifton, Georgia.

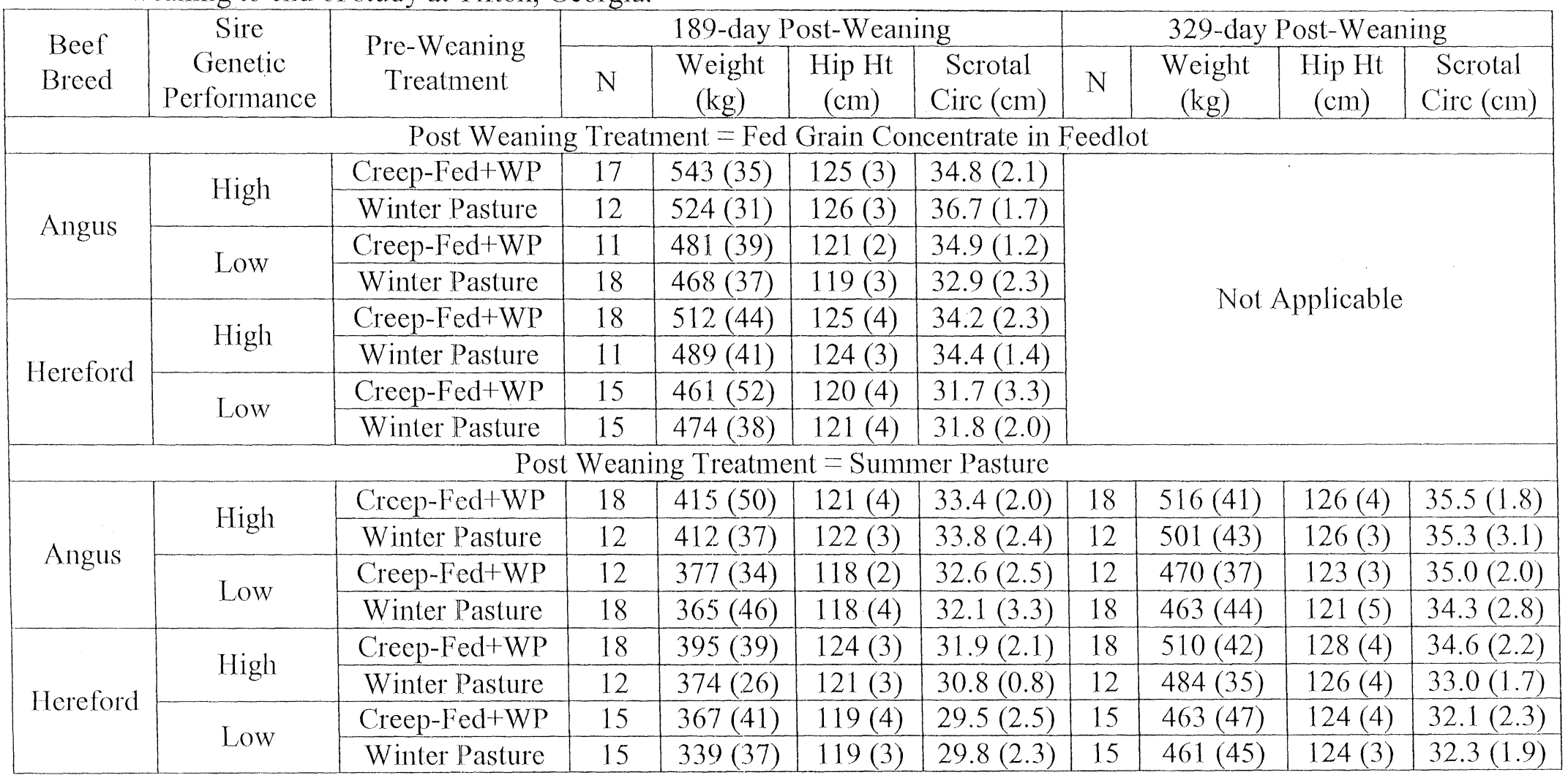

Notes: Genetic performance level applies to the sire of the calf. It was determined by ranking the sires when they were calves. The highest ranked five to eight young bulls each year were identified as high performance (ranking of ADG + WDA

[weight per day of age]), while the five to eight lowest ranked bulls were identified as low performance. JD = Julian day. Circ $=$ Circumference. Number in parenthesis is the standard deviation. 
Table A3. Simple statistics describing the 239 bull calves by year and 114 bull calves for the summer pasture level of post-weaning treatment by year over the period from birth to end of study at Tifton, Georgia.

\begin{tabular}{|l|c|c|c|c|c|}
\hline Variable Measured & 1985 & 1986 & 1987 & 1988 & 1989 \\
\hline Initial Sample Size & 47 & 48 & 48 & 48 & 48 \\
\hline Age of Dam (y) & $5.9(3.1)$ & $5.6(2.5)$ & $6.2(2.6)$ & $6.0(2.8)$ & $6.3(3.0)$ \\
\hline Initial Sample Size & 24 & 24 & 24 & 18 & 24 \\
\hline Birth Date (JD) & $348(10)$ & $345(14)$ & $336(18)$ & $341(22)$ & $344(13)$ \\
\hline Birth Weight (kg) & $33.2(6)$ & $34.8(4)$ & $32.8(5)$ & $36.0(6)$ & $36.0(4)$ \\
\hline Weaning Age (d) & $234(10)$ & $231(14)$ & $228(18)$ & $231(22)$ & $233(13)$ \\
\hline Weaning Weight (kg) & $237(28)$ & $239(33)$ & $220(35)$ & $238(28)$ & $231(30)$ \\
\hline Weaning Hip Height (cm) & $108(3)$ & $108(4)$ & $104(4)$ & $110(4)$ & $109(4)$ \\
\hline Weaning Scrotal Circ (cm) & $23.6(1.7)$ & $23.7(2.8)$ & $20.2(2.7)$ & $21.9(2.9)$ & $21.1(2.6)$ \\
\hline End of 189-day Study (part) & 24 & 24 & 24 & 17 & 24 \\
\hline 189-day Weight (kg) & $429(57)$ & $427(88)$ & $405(82)$ & $445(71)$ & $436(60)$ \\
\hline 189-day Hip Height (cm) & $121(3)$ & $120(4)$ & $118(4)$ & $123(4)$ & $122(4)$ \\
\hline 189-day Scrotal Circ (cm) & $32.8(2.1)$ & $33.5(3.0)$ & $30.5(2.2)$ & $33.9(3.0)$ & $33.0(3.3)$ \\
\hline End of 329-day Study & 12 & 12 & 12 & 9 & 12 \\
\hline 329-day Weight (kg) & $506(35)$ & $488(38)$ & $454(45)$ & $468(22)$ & $457(53)$ \\
\hline 329-day Hip Height (cm) & -- & $124(4)$ & $120(5)$ & $127(4)$ & $126(3)$ \\
\hline 329-day Scrotal Circ (cm) & $34.4(2.4)$ & $35.0(2.9)$ & $32.2(2.1)$ & $33.1(3.0)$ & $33.7(2.4)$ \\
\hline
\end{tabular}

Notes: Genetic performance level applies to the sire of the calf. It was determined by ranking the sires when they were calves. The highest ranked five to eight young bulls each year were identified as high performance (ranking of ADG + WDA [weight per day of age]), while the five to eight lowest ranked bulls were identified as low performance. JD = Julian day. Circ = Circumference. Number in parenthesis is the standard deviation. '- - ' denotes data was not taken. Only the summer pasture young bulls were kept for the portion of the study that continued on from day 189 to day 329. All feedlot young bulls were either returned to the herd at Tifton, Georgia, or sold at auction. 
Among the pool of all Angus yearling bulls from the 1983-1984 calving season, select two or three bulls with highest $A D G$ (Line $=H$ ), and select two or three bulls with lowest $A D G$ (Line $=L$ )

Place each bull from Line=H with $30-40$ cows, select first 24 dam-bull calf pairs.

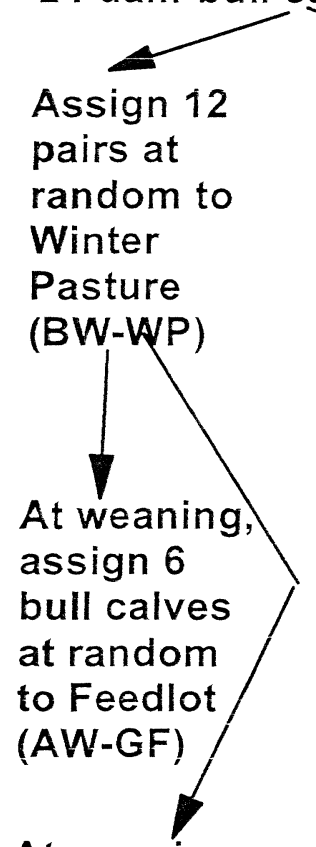

At weaning, assign 6 bull calves at random to Summer Pasture (AW-SP)

\section{Assign 12 pairs} at random to Winter Pasture plus Creep Feeders (BW-CP)

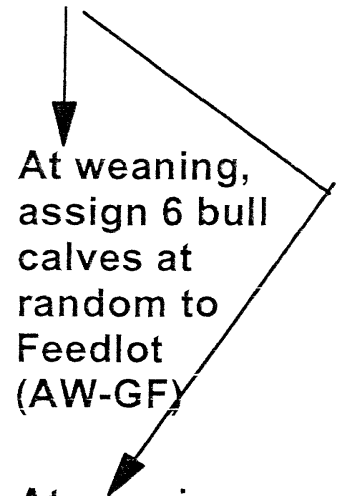

At weaning, assign 6 bull calves at random to Summer Pasture (AW-SP)

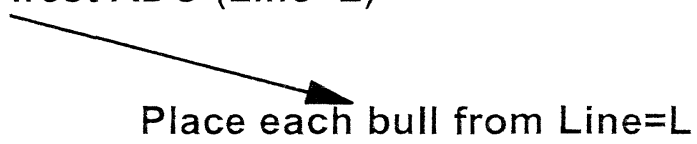
with $30-40$ cows, select first 24 dam-bull calf pairs.

$\begin{array}{ll}\text { Assign } 12 & \text { Assign } 12 \text { pairs } \\ \text { pairs at } & \text { at random to } \\ \text { random to } & \text { Winter Pasture } \\ \text { Winter } & \text { plus Creep } \\ \text { Pasture } & \text { Feeders }\end{array}$

(BW-CP)

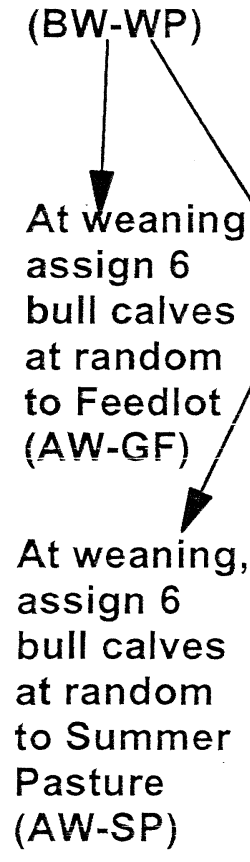

Figure 1. Flow chart depicting the assignment of young Angus bulls after weaning to their post-weaning treatment in 1985. This was repeated for young Hereford bulls in 1985. This was repeated for both young Angus and Hereford bulls in 1986, 1987, 1988 , and 1989. 
Figure 2a. Effect of high and low genetic performance and creep-fed + winter pasture and winter pasture only on changes in ranked post-weaning ADG (predicted) over 189 days of grain concentrate fed to weaned Angus bulls in feedlot.

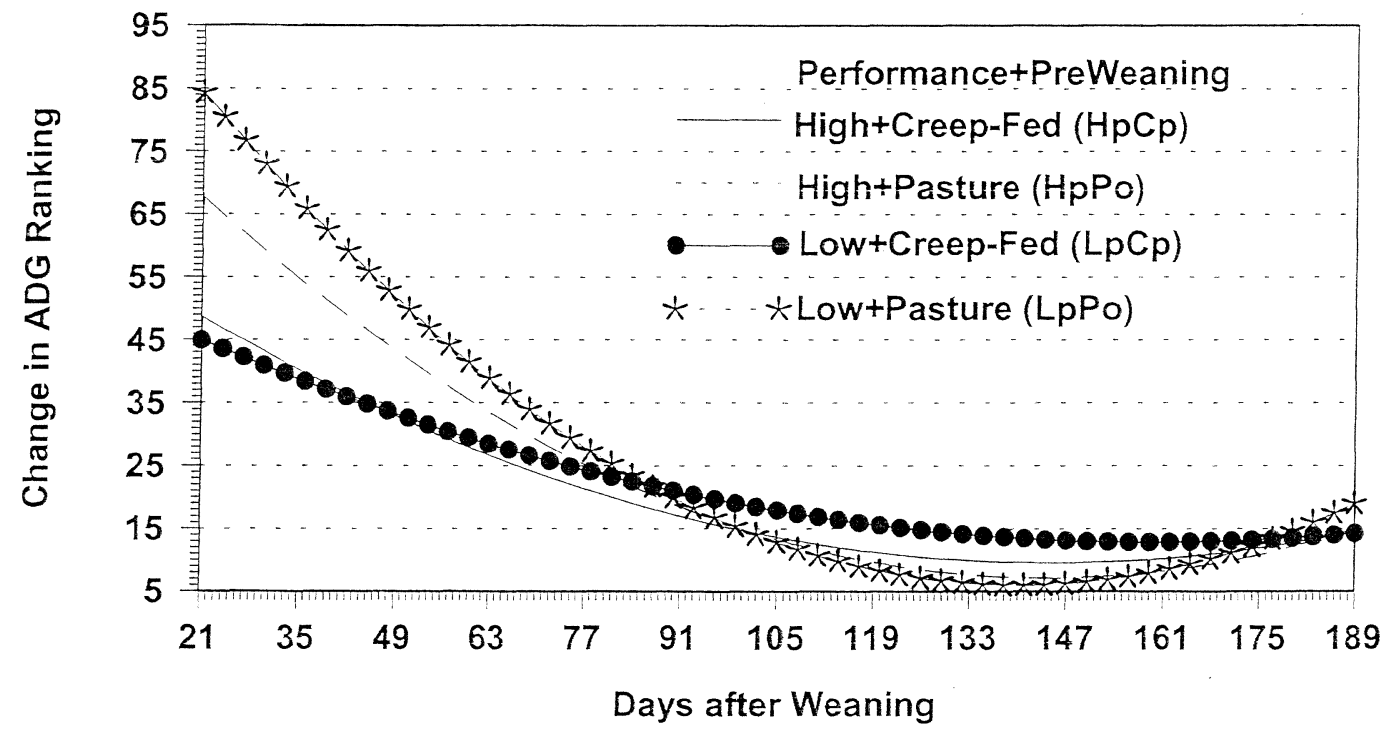

Figure $2 \mathrm{~b}$. Effect of high and low genetic performance and creep-fed + winter pasture and winter pasture only on changes in ranked post-weaning ADG (predicted) over 189 days of weaned Angus bulls on summer pasture.

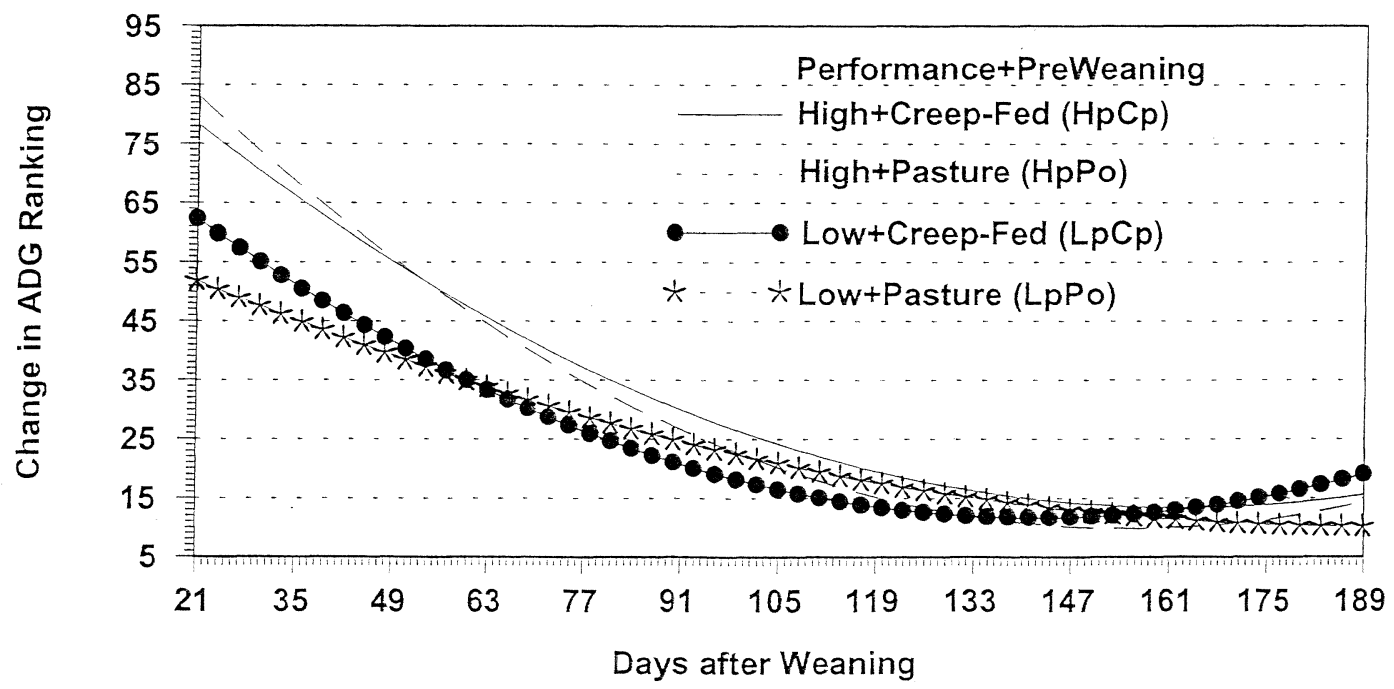


Figure 3a. Effect of high and low genetic performance and creep-fed + winter pasture and winter pasture only on changes in ranked post-weaning ADG (predicted) over 189 days of grain concentrate fed to weaned Hereford bulls in feedlot.

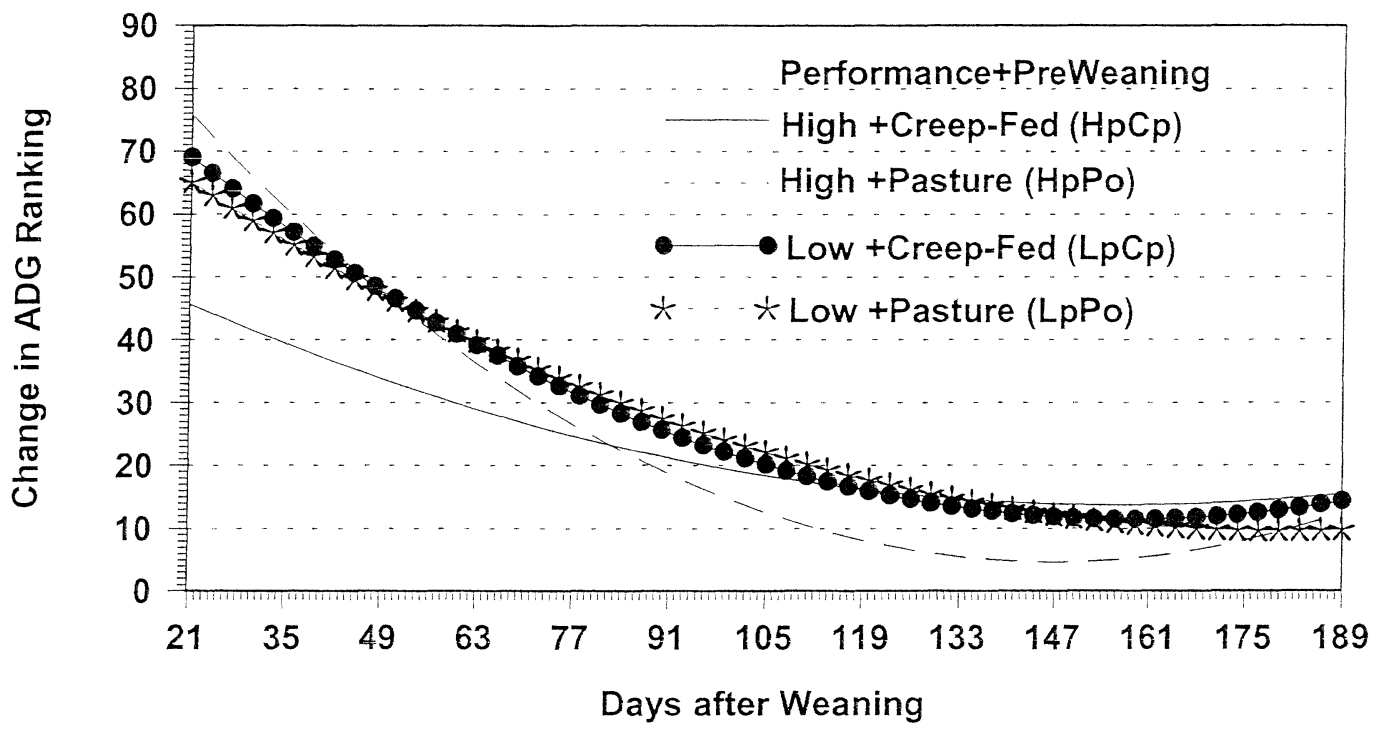

Figure $3 b$. Effect of high and low genetic performance and creep-fed + winter pasture and winter pasture only on changes in ranked post-weaning ADG (predicted) over 189 days of weaned Hereford bulls on summer pasture.

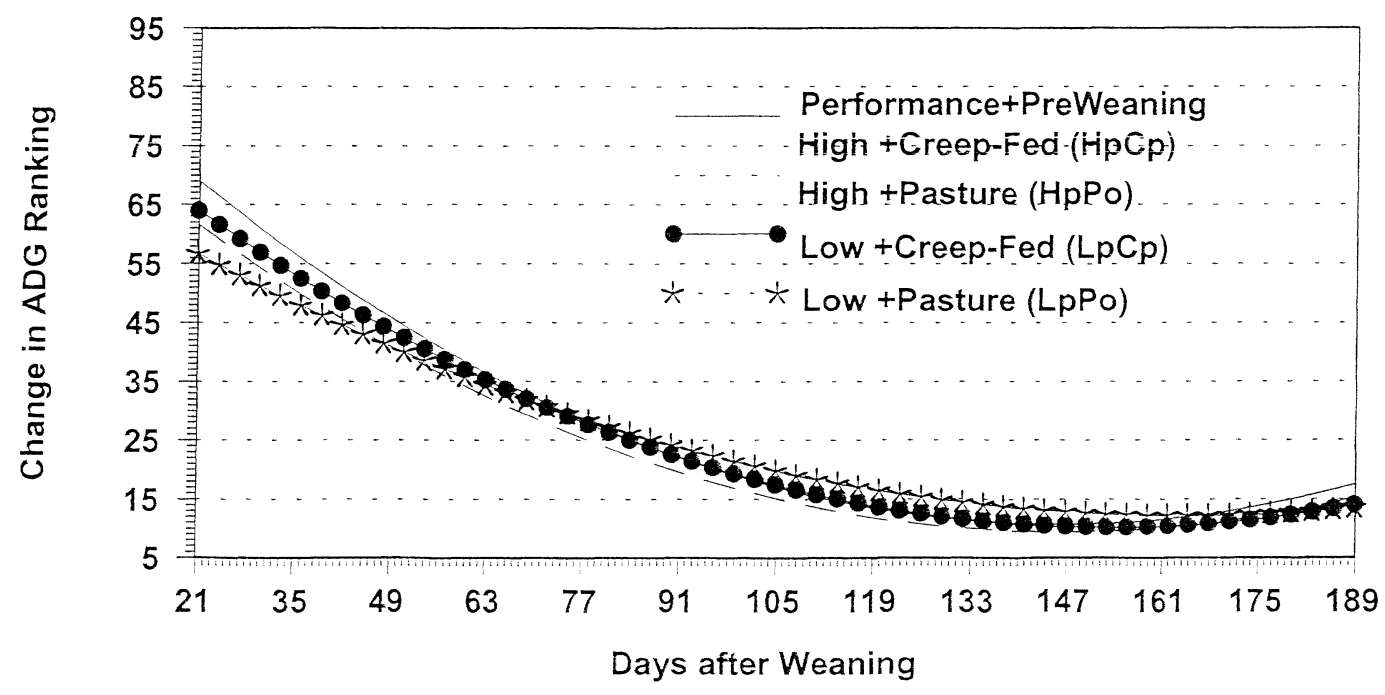

